\title{
Partial Purification and Characterization of Rhodanese from Rainbow Trout (Oncorhynchus mykiss) Liver
}

\author{
Hossein Tayefi-Nasrabadi and Reza Rahmani \\ Department of Basic Sciences, College of Veterinary Medicine, University of Tabriz, P.O. Box 51666-16471, Tabriz, Iran \\ Correspondence should be addressed to Hossein Tayefi-Nasrabadi, tayefi@tabrizu.ac.ir
}

Received 31 October 2011; Accepted 29 December 2011

Academic Editor: Marc Edery

Copyright (C) 2012 H. Tayefi-Nasrabadi and R. Rahmani. This is an open access article distributed under the Creative Commons Attribution License, which permits unrestricted use, distribution, and reproduction in any medium, provided the original work is properly cited.

Cyanide is one of the most toxic substances present in a wide variety of food materials that are consumed by animals. Rhodanese, a ubiquitous enzyme, can catalyse the detoxification of cyanide by sulphuration reaction. In this study, rhodanese was partially purified and characterized from the liver tissue homogenate of the rainbow trout. The enzyme was active in a broad range of $\mathrm{pH}$, from 5 to 12 . The optimal activity was found at a high $\mathrm{pH}(\mathrm{pH} 10.5)$, and the temperature optimum was $25^{\circ} \mathrm{C}$. The enzyme was heat labile, losing $>50 \%$ of relative activity after only 5 min of incubation at $40^{\circ} \mathrm{C}$. The $K_{m}$ values for $\mathrm{KCN}$ and $\mathrm{Na}_{2} \mathrm{~S}_{2} \mathrm{O}_{3}$ as substrates were $36.81 \mathrm{mM}$ and $19.84 \mathrm{mM}$, respectively. Studies on the enzyme with a number of cations showed that the activity of the enzyme was not affected by $\mathrm{Sn}^{2+}$, but $\mathrm{Hg}^{2+}, \mathrm{Ba}^{2+}, \mathrm{Pb}^{2+}$, and $\mathrm{Ca}^{2+}$ inhibited and $\mathrm{Cu}^{2+}$ activated the enzyme with a concentration-dependent manner.

\section{Introduction}

Rhodanese (thiosulphate: cyanide sulphurtransferase, EC 2.8.1.1) is a sulphur transferase that catalyses the formation of thiocyanate from free cyanide and a sulphur donor. It is a ubiquitous enzyme that is active in bacteria, yeast, plants, and animals $[1,2]$. Beside cyanide detoxification, many other physiological functions have been proposed for rhodanese enzyme: it supplies sulphide for the formation of iron-sulphur centres, thiamine biosynthesis, maintains the sulphane pool, participates in selenium metabolism, and functions as a thioredoxin oxidase [3-5]. Intracellular study of the enzyme revealed that it is present in the cytosol, mitochondrion, and nucleus [6].

In aquatic organisms, freshwater fish are the most cyanide-sensitive group with high mortality at free cyanide concentrations above $20 \mu \mathrm{g} / \mathrm{L}$. Studies on cyanide toxicity in fish indicate that it has adverse effects on swimming and reproduction at $>5 \mu \mathrm{g} / \mathrm{L}[7]$.

The rainbow trout (Oncorhynchus mykiss) is a species of salmonid native to tributaries of the Pacific Ocean in Asia and North America. This species constitutes the major group of cultured freshwater fish with great commercial importance. This paper reports on the partial purification and characterization of rhodanese isolated in the liver of rainbow trout.

\section{Materials and Methods}

2.1. Chemicals. Ammonium sulphate (enzyme grade), potassium cyanide, and sodium thiosulphate (pentahydrate) were obtained from Sigma Chemical Company, St. Louis, USA. All other reagents were of analytical grade and were obtained from Merck (Darmstadt, Germany).

2.2. Enzyme Preparation. Live fish weighing $350-450 \mathrm{~g}$ were obtained from local fish dealers, transported live to the laboratory, sacrificed, and then dissected. Liver was quickly removed and washed with physiological saline. Liver extracts were prepared by freezing the samples in liquid nitrogen, homogenizing with a hand homogenizer, and suspending the homogenates in $25 \mathrm{mM}$ sodium phosphate buffer, $\mathrm{pH}$ 7.2. The suspensions were centrifuged for $10 \mathrm{~min}$ at $4,000 \mathrm{rpm}$. Supernatant was brought to $65 \%$ ammonium sulphate saturation $(430 \mathrm{~g} / \mathrm{L})$ by the addition of solid ammonium sulphate over a period of 1 hour with continuous stirring and then left overnight. The resulting precipitate was collected by centrifugation at $4,000 \mathrm{rpm}$ for $15 \mathrm{~min}$ and immediately 
TABLE 1: Summary of the partial purification of rainbow trout liver rhodanese.

\begin{tabular}{lcccccc}
\hline Fraction & Volume $(\mathrm{mL})$ & $\begin{array}{c}\text { Total activity } \\
\left(\mathrm{U} \cdot \mathrm{mL}^{-1}\right)\end{array}$ & $\begin{array}{c}\text { Total protein } \\
(\mathrm{mg})\end{array}$ & $\begin{array}{c}\text { Specific activity } \\
\left(\mathrm{U} \cdot \mathrm{mg}^{-1} \text { pro.) }\right.\end{array}$ & $\begin{array}{c}\text { Yield }(\%) \\
\text { Purification } \\
\text { fold }\end{array}$ \\
\hline Crude extract & 105 & 157.99 & 1295.76 & 0.121 & 100 & 1 \\
$65 \%$ ammonium sulphate precipitation & 45 & 49.83 & 241.83 & 0.206 & 31.5 & 1.7 \\
\hline
\end{tabular}

dialyzed against several changes of a $50 \mathrm{mM}$ citrate buffer, $\mathrm{pH}$ 5.0. The dialysate was centrifuged at $13,400 \mathrm{rpm}$ for $15 \mathrm{~min}$ to remove insoluble materials.

2.3. Enzyme Assay. Rhodanese was assayed by the modified method of Sorbo [8]. The reaction mixture consisted of a $25 \mathrm{mM}$ citrate-phosphate-borate buffer, at given $\mathrm{pH}, 50 \mathrm{mM}$ $\mathrm{KCN}, 50 \mathrm{mM} \mathrm{Na} \mathrm{S}_{2} \mathrm{O}_{3}$, and $50 \mu \mathrm{L}$ enzyme in a total volume of $1.75 \mathrm{~mL}$. The mixture was incubated for $2 \mathrm{~min}$ at $25^{\circ} \mathrm{C}$, and the reaction was stopped by the addition of $0.25 \mathrm{~mL}$ of $37 \%$ formaldehyde, followed by the addition of $1 \mathrm{~mL}$ of ferric nitrate solution containing $0.025 \mathrm{~g} \mathrm{Fe}(\mathrm{NO} 3) 39 \mathrm{H} 2 \mathrm{O}$ in $0.74 \mathrm{~mL}$ water and $0.26 \mathrm{~mL}$ concentrated nitric acid. The absorbance was then read at $460 \mathrm{~nm}$. Reaction velocity was computed from linear slopes of absorbance-time curve. One unit of rhodanese activity was defined as micromole of thiocyanate formed per min. Protein concentrations were determined by the method of Lowry et al. [9], using crystalline bovine serum albumin as standard.

2.4. Kinetic Studies. The $K_{m}$ for cyanide ion was determined by varying the concentration of $\mathrm{KCN}$ between $10 \mathrm{mM}$ and $50 \mathrm{mM}$ at $50 \mathrm{mM} \mathrm{Na}_{2} \mathrm{~S}_{2} \mathrm{O}_{3}$. Also, $K_{m}$ for sodium thiosulphate was determined by varying the $\mathrm{Na}_{2} \mathrm{~S}_{2} \mathrm{O}_{3}$ concentration from $10 \mathrm{mM}$ to $50 \mathrm{mM}$ at $50 \mathrm{mM}$ of KCN.

2.5. Effect of $p H$. The effect of $\mathrm{pH}$ on the rainbow trout liver rhodanese was assessed by assaying the enzyme at different $\mathrm{pH}$ using TS buffer (citrate-phosphate-borate, $25 \mathrm{mM}, \mathrm{pH}$ 12).

2.6. Effect of Temperature. For determination of optimum temperature of enzyme activity, $50 \mu \mathrm{L}$ of the enzyme was assayed at temperatures between $20^{\circ}$ and $70^{\circ} \mathrm{C}$. The reaction mixture was first incubated at the selected temperature for $10 \mathrm{~min}$ before initiating the reaction by the addition of the enzyme that had been equilibrated at the same temperature.

Thermal stability of liver rhodanese was studied by incubating aliquots of enzyme at various temperatures (25, $30,40,50,60$ and $70^{\circ} \mathrm{C}$ ) up to $60 \mathrm{~min}$ in a thermostatic water bath and measuring their activity at room temperature after brief cooling in ice. The incubation was carried out in sealed vials to prevent change of volume of the sample and, hence, the enzyme concentration due to evaporation.

2.7. Effect of Cations. Rhodanese activity was measured in the presence (final concentration 0.5 or $1 \mathrm{mM}$ ) and absence of various ionic compounds $\left(\mathrm{SnCl}_{2}, \mathrm{HgCl}_{2}, \mathrm{BaCl}_{2}, \mathrm{PbCl}_{2}\right.$, $\mathrm{CaCl}_{2}$, and $\mathrm{CuCl}_{2}$ ) under the standard conditions.

All assays were done at least in 3 separate experiments, and the mean values of data were reported.

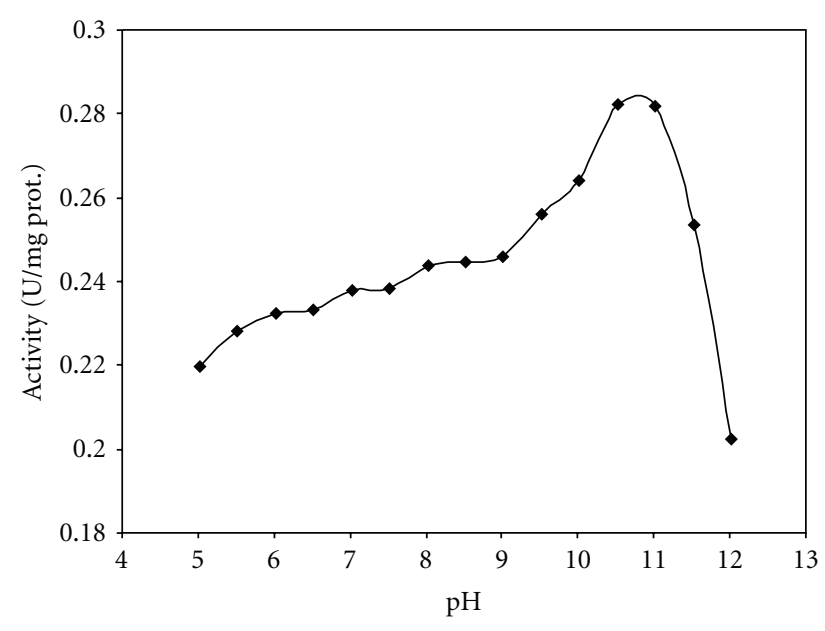

Figure 1: Effect of $\mathrm{pH}$ on rainbow trout liver rhodanese. The assay mixture contained $25 \mathrm{mM}$ citrate-phosphate-borate buffer, at given $\mathrm{pH}$, and $50 \mathrm{mM} \mathrm{KCN}, 50 \mathrm{mM} \mathrm{Na}_{2} \mathrm{~S}_{2} \mathrm{O}_{3}$, and $50 \mu \mathrm{L}$ enzyme solution in a total volume of $1.75 \mathrm{~mL}$.

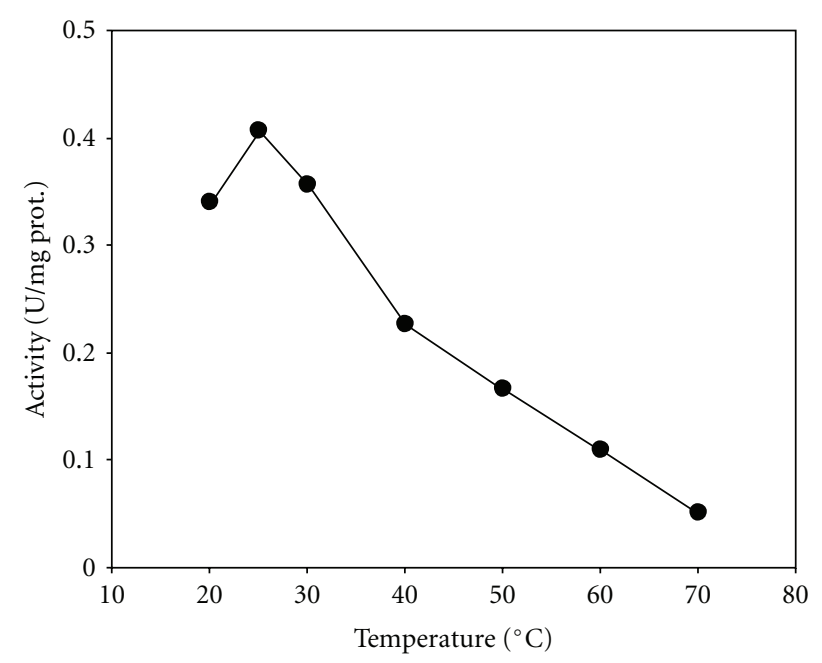

FIGURE 2: Effect of temperature on rainbow trout liver rhodanese.

\section{Results}

Table 1 shows the results of the partial purification of rhodanese from the liver of rainbow trout. The specific activity of enzyme after partial purification using ammonium sulphate precipitation and dialysis was $0.206 \mathrm{U} / \mathrm{mg}$. The effect of $\mathrm{pH}$ on the rate of rhodanese activity is shown in Figure 1. Rhodanese activity was found in $\mathrm{pH}$ ranging from 5 to 12. An optimum $\mathrm{pH}$ of 10.5 was obtained. The effect of temperatures between 20 and $70^{\circ} \mathrm{C}$ on the rhodanese activity showed that optimum temperature for the enzyme was $25^{\circ} \mathrm{C}$ (Figure 2). The enzyme was incubated at different 
TABLE 2: Comparison of $K_{m}$ values for rainbow trout liver with other liver rhodanese preparations.

\begin{tabular}{lccccccc}
\hline Substrate & Rainbow trout & African catfish $^{\mathrm{a}}$ & Mudskipper $^{\mathrm{b}}$ & $\begin{array}{c}K_{m}(\mathrm{mM}) \\
\text { Fruit bat }^{\mathrm{c}}\end{array}$ & Mouse $^{\mathrm{d}}$ & Bovine $^{\mathrm{e}}$ & Human $^{\mathrm{f}}$ \\
\hline $\mathrm{KCN}$ & 36.81 & 25.4 & 33.3 & 13.36 & 12.5 & 19.0 & 9.5 \\
$\mathrm{Na}_{2} \mathrm{~S}_{2} \mathrm{O}_{3}$ & 19.84 & 18.6 & 14.29 & 19.15 & 8.3 & 6.7 & 4.5 \\
\hline
\end{tabular}

Data obtained from references [10-15].

TABLE 3: Effect of cations on rainbow trout liver rhodanese activity.

\begin{tabular}{lcc}
\hline Salt & \multicolumn{2}{c}{ Enzyme activity (\%) } \\
& $0.5 \mathrm{mM}$ & $1.0 \mathrm{mM}$ \\
\hline None & 100 & 100 \\
$\mathrm{SnCl}_{2}$ & 100 & 100 \\
$\mathrm{CuCl}_{2}$ & 206 & 351 \\
$\mathrm{HgCl}_{2}$ & 95 & 92 \\
$\mathrm{CaCl}_{2}$ & 94 & 76 \\
$\mathrm{BaCl}_{2}$ & 93 & 87 \\
$\mathrm{PbCl}_{2}$ & 98 & 66 \\
\hline
\end{tabular}

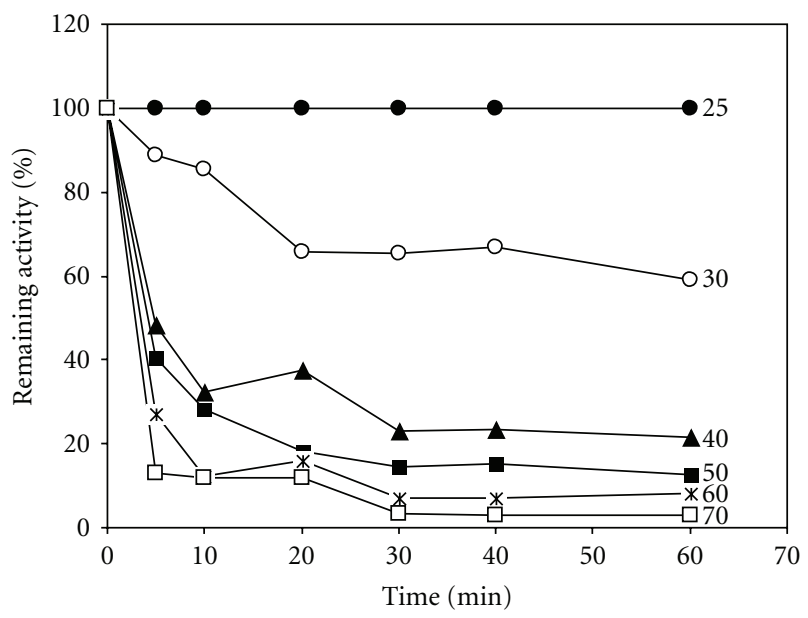

Figure 3: Effect of heat treatment on rainbow trout rhodanese activity as a function of treatment time at different temperatures. The remaining activity was expressed as a percentage of activity of the enzyme incubated at $25^{\circ} \mathrm{C}$.

temperatures for $60 \mathrm{~min}$ and, after brief cooling in ice, the residual enzyme activity was measured (Figure 3 ). It was found that the enzyme was stable at $25^{\circ} \mathrm{C}$ for $60 \mathrm{~min}$ but was unstable at temperatures $\geq 30^{\circ} \mathrm{C}$. Michaelis constants $\left(K_{m}\right)$ and maximum reaction velocities $\left(V_{\max }\right)$ of the rainbow trout liver rhodanese were determined using LineweaverBurk plot under optimum conditions (Figures 4(a) and $4(\mathrm{~b}))$. The $K_{m}$ values for $\mathrm{KCN}$ and $\mathrm{Na}_{2} \mathrm{~S}_{2} \mathrm{O}_{3}$ were $36.81 \mathrm{mM}$ and $19.84 \mathrm{mM}$, and the $V_{\max }$ values for these substrates (KCN and $\mathrm{Na}_{2} \mathrm{~S}_{2} \mathrm{O}_{3}$ ) were 0.924 and $0.423 \mathrm{U} / \mathrm{mg}$, respectively. A comparison of rainbow trout rhodanese with some other rhodanese preparations is shown in Table 2. The result of the effect of various cations on the activity of rhodanese is presented in Table 3.

\section{Discussion}

Cyanide is a potent cytotoxic agent that kills the cell by inhibiting cytochrome oxidase of the mitochondrial electron transport chain. When ingested, cyanide activates the body own mechanisms of detoxification, resulting in the transformation of cyanide into a less toxic compound, thiocyanate. Rhodanese and 3-mercaptopyruvate sulphurtransferase represent the chief enzymes of cyanide detoxification $[1,2]$. Rainbow trout constitutes the major group of cultured freshwater fish with great commercial importance. This research shows the existence of rhodanese in the rainbow trout liver homogenate. The enzyme was partially purified by ammonium sulphate precipitation and dialysis. As shown in Figure 1, optimum $\mathrm{pH}$ for rainbow trout liver rhodanese was 10.5. This value is greater than the values found for rhodanese of bovine liver (between 8.0 and 9.0) [8, 14], mouse liver (9.4) [13], African catfish liver (6.5) [10], fruit bat liver (9) [12], and mudskipper liver (8) [11]. Chew and Boey [16], working on the tapioca leaf, obtained a high $\mathrm{pH}$ value of $10.2-11$, which is very close to the $\mathrm{pH}$ optimum of rainbow trout liver rhodanese.

Different optimum temperatures have been reported for rhodanese from different organisms. Akinsiku et al. [10], reported $40^{\circ} \mathrm{C}$ for the rhodanese from the liver of the African catfish from Asejire Lake. Himwich and Saunders [17] also obtained an optimum temperature of between $38^{\circ} \mathrm{C}$ and $40^{\circ} \mathrm{C}$ for bovine liver rhodanese. Agboola and Okonji [12] reported $35^{\circ} \mathrm{C}$ for the rhodanese in the cytosolic fraction of fruit bat liver. In an earlier study, Emuebie et al. [11] obtained the high optimum temperature of $50^{\circ} \mathrm{C}$ for mudskipper liver rhodanese. The optimum temperature obtained was $25^{\circ} \mathrm{C}$ for rhodanese from the liver of the rainbow trout. The thermal stability experiment showed that the enzyme was heat labile, losing about $52 \%$ of relative activity after only $5 \mathrm{~min}$ of incubation at $40^{\circ} \mathrm{C}$. The enzyme retained $59,21,12,8$, and $3 \%$ of its activity at $30,40,50,60$, and $70^{\circ} \mathrm{C}$ when heated for 1 hour. Ploegman et al. [18] reported that rhodanese consists of two equally sized, similarly folded domains stabilized by extensive hydrophobic interactions. The active site resides in a deep cavity formed by the juxtaposition of these domains. This enzyme appears sensitive to thermal inactivation, a process which apparently results from thermally induced transitions of the native structure, which lead to the exposure of hydrophobic surfaces and irreversible protein association [19].

The apparent $K_{m}$ values, as determined by the Lineweaver-Burk plot for $\mathrm{KCN}$ and $\mathrm{Na}_{2} \mathrm{~S}_{2} \mathrm{O}_{3}$, were 36.81 and $19.84 \mathrm{mM}$, respectively, for liver of the rainbow trout. These values are compared to those reported in earlier studies in 


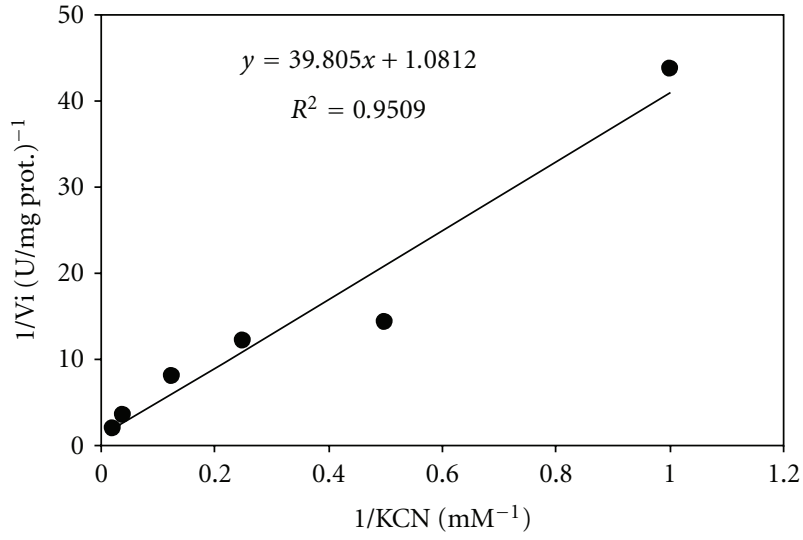

(a)

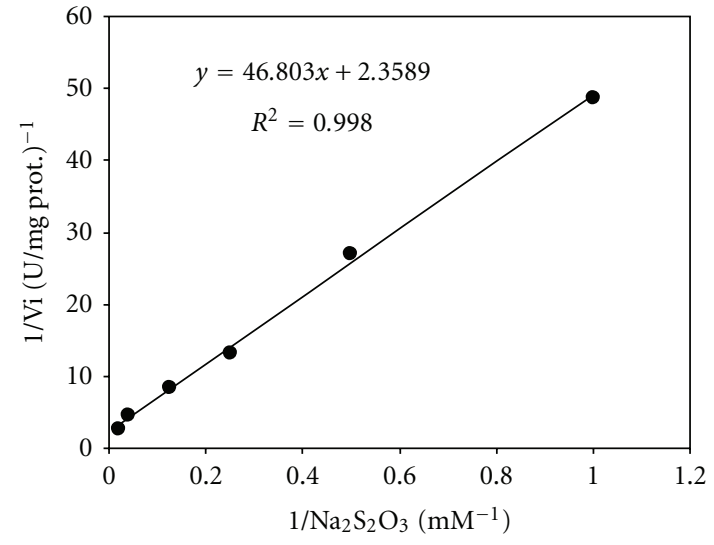

(b)

FIGURE 4: Lineweaver-Burk plot for the determination of the kinetic parameters of rainbow trout rhodanese. The enzyme was assayed at varying concentrations of $\mathrm{Na}_{2} \mathrm{~S}_{2} \mathrm{O}_{3}$ at $50 \mathrm{mM} \mathrm{KCN} \mathrm{(a)} \mathrm{and} \mathrm{varying} \mathrm{concentrations} \mathrm{of} \mathrm{KCN}$ at $50 \mathrm{mM} \mathrm{Na}_{2} \mathrm{~S}_{2} \mathrm{O}_{3}$ (b). The reaction mixture consisted of a $25 \mathrm{mM}$ citrate-phosphate-borate buffer, $\mathrm{pH} 10.5$, and $50 \mu \mathrm{L}$ enzyme in a total volume of $1.75 \mathrm{~mL}$ at $25^{\circ} \mathrm{C}$.

Table 2. As shown in Table 2, the $K_{m}$ values of rainbow trout liver rhodanese are higher than those of African catfish liver, mudskipper liver, fruit bat liver, mouse liver, bovine liver, and human liver, indicating that the affinity of the rainbow trout enzyme for these substrates is less than that of the other enzymes and that it would catalyze the detoxification reaction with less efficiency. As reported by Agboola and Okonji [12] this less effective enzymatic system may be due to a lower exposure to cyanide, in contrast to its mammalian animals, which are continually exposed through their diet. However, it should be noted that cyanide detoxification is a secondary benefit of rhodanese, which has a number of major physiological roles, including the supply of sulphide for the formation of iron-sulphur centres for the electron transport chain.

Specific binding sites for some metal ions have been crystallographically documented for a reduced number of proteins, including rhodanese [20]. In some of these cases, the binding of the cation has been found to promote functional effects [21]. In this study, the effect of some metal ions such as $\mathrm{Sn}^{2+}, \mathrm{Hg}^{2+}, \mathrm{Ba}^{2+}, \mathrm{Pb}^{2+}, \mathrm{Cu}^{2+}$, and $\mathrm{Ca}^{2+}$ on activity of rainbow trout liver rhodanese was also studied. Results show that between these cations, only $\mathrm{Cu}^{2+}$ could activate the enzyme, but $\mathrm{Hg}^{2+}, \mathrm{Ba}^{2+}, \mathrm{Pb}^{2+}, \mathrm{Cu}^{2+}$, and $\mathrm{Ca}^{2+}$ inhibited the enzyme by dose-dependent manner, respectively.

A great deal of the beneficiary as well as detrimental effects of transition metals comes from these metals ability to coordinate to protein residues and any protein may have more than one binding site for a given metal. Metal ion is known to bind to peptides and proteins, and a number of potential metal-binding residues, including cysteine, histidine, tyrosine, and asparagines, have been identified. Changes in the tertiary and secondary structure of the enzyme were also reported after incubation of protein with metal ions [22]. The inhibition or activation of rainbow trout liver rhodanese by these cations is probably due to the interaction of these metal ions with sulphydryl groups at the enzyme catalytic site [23] or induction of changes in conformation of enzyme. Further experimental studies are required to elucidate the mechanism of activation or inhibition of the enzyme with these metal ions. In conclusion, the biochemical parameters obtained would confirm the enzyme to function in the conversion of cyanide, from various sources in the water, to thiocyanate and thereby presumably in the detoxification of the poisonous cyanide, ultimately improving the survival of the fish in polluted water.

\section{Conflict of Interests}

The authors declares that there is no conflict of interests.

\section{Acknowledgment}

The financial support of the research affair of the University of Tabriz is highly appreciated.

\section{References}

[1] M. Aminlari, A. Li, V. Kunanithy, and C. H. Scaman, "Rhodanese distribution in porcine (Sus scrofa) tissues," Comparative Biochemistry and Physiology B, vol. 132, no. 2, pp. 309-313, 2002.

[2] N. Nagahara, T. Ito, and M. Minam, "Mercaptopyruvate sulfurtransferase as a defense against cyanide toxication: molecular properties and mode of detoxification," Histology and Histopathology, vol. 14, no. 4, pp. 1277-1286, 1999.

[3] J. Smith and K. M. Urbanska, "Rhodanese activity in Lotus corniculatus sensu-lato," Journal of Natural History, vol. 20, pp. 1467-1476, 1986.

[4] D. Bordo and P. Bork, "The rhodanese/Cdc25 phosphatase superfamily. Sequence-structure-function relations," EMBO Reports, vol. 3, no. 8, pp. 741-746, 2002.

[5] D. L. Nandi, P. M. Horowitz, and J. Westley, "Rhodanese as a thioredoxin oxidase," International Journal of Biochemistry and Cell Biology, vol. 32, no. 4, pp. 465-473, 2000. 
[6] A. A. Al-Qarawi, H. M. Mousa, and B. H. Ali, "Tissue and intracellular distribution of rhodanese and mercaptopyruvate sulphurtransferase in ruminants and birds," Veterinary Research, vol. 32, no. 1, pp. 63-70, 2001.

[7] R. Eisler and S. N. Wiemeyer, "Cyanide hazards to plants and animals from gold mining and related water issues," Reviews of Environmental Contamination and Toxicology, vol. 183, pp. 21-54, 2004.

[8] B. H. Sorbo, "Crystalline rhodanese-I. Purification and physicochemical examination," Acta Chemica Scandinavica, vol. 7, pp. 1129-1136, 1953.

[9] O. H. Lowry, N. J. Rosebrough, A. L. Farr, and R. J. Randall, "Protein measurement with the Folin phenol reagent," The Journal of Biological Chemistry, vol. 193, no. 1, pp. 265-275, 1951.

[10] O. T. Akinsiku, F. K. Agboola, A. Kuku, and A. Afolayan, "Physicochemical and kinetic characteristics of rhodanese from the liver of African catfish Clarias gariepinus Burchell in Asejire lake," Fish Physiology and Biochemistry, vol. 36, no. 3, pp. 573-586, 2010.

[11] O. R. Emuebie, A. H. Adedayo, K. Adenike, and A. F. Kayode, "Physicochemical properties of mudskipper (Periophthalmus barbarus pallas) liver rhodanese," Australian Journal of Basic and Applied Sciences, vol. 5, no. 8, pp. 507-514, 2011.

[12] F. K. Agboola and R. E. Okonji, "Presence of rhodanese in the cytosolic fraction of the fruit bat (Eidolon helvum) liver," Journal of Biochemistry and Molecular Biology, vol. 37, no. 3, pp. 275-281, 2004.

[13] C. H. Lee, J. H. Hwang, Y. S. Lee, and K. S. Cho, "Purification and characterization of mouse liver rhodanese," Journal of Biochemistry and Molecular Biology, vol. 28, pp. 170-176, 1995.

[14] B. H. Sorbo, "Crystalline rhodanese. Enzyme catalyzed reaction," Acta Chemica Scandinavica, vol. 7, pp. 1137-1145, 1953.

[15] R. Jarabak and J. Westley, "Human liver rhodanese. Nonlinear kinetic behavior in a double displacement mechanism," Biochemistry, vol. 13, no. 16, pp. 3233-3236, 1974.

[16] M. Y. Chew and C. G. Boey, "Rhodanese of tapioca leaf," Phytochemistry, vol. 11, no. 1, pp. 167-169, 1972.

[17] W. A. Himwich and J. B. Saunders, "Enzymic conversion of cyanide to thiocyanate," American Journal of Physiology, vol. 53, pp. 348-354, 1948.

[18] J. H. Ploegman, G. Drent, and K. H. Kalk, "The covalent and tertiary structure of bovine liver rhodanese," Nature, vol. 273, no. 5658, pp. 124-129, 1978.

[19] P. Horowitz and S. Bowman, "Reversible thermal denaturation of immobilized rhodanese," Journal of Biological Chemistry, vol. 262, no. 12, pp. 5587-5591, 1987.

[20] L. J. Lijk, C. A. Torfs, K. H. Kalk, M. C. De Maeyer, and W. G. Hol, "Differences in the binding of sulfate, selenate and thiosulfate ions to bovine liver rhodanese, and a description of a binding site for ammonium and sodium ions. An X-ray diffraction study," European Journal of Biochemistry, vol. 142, no. 2, pp. 399-408, 1984.

[21] M. D. Toney, E. Hohenester, S. W. Cowan, and J. N. Jansonius, "Dialkylglycine decarboxylase structure: bifunctional active site and alkali metal sites," Science, vol. 261, no. 5122, pp. 756759, 1993.

[22] H. Tayefi-Nasrabadi, E. Keyhani, and J. Keyhani, "Conformational changes and activity alterations induced by nickel ion in horseradish peroxidase," Biochimie, vol. 88, no. 9, pp. 1183 1197, 2006.
[23] N. Nagahara and T. Nishino, "Role of amino acid residues in the active site of rat liver mercaptopyruvate sulfurtransferase: cDNA cloning, overexpression, and site- directed mutagenesis," Journal of Biological Chemistry, vol. 271, no. 44, pp. 27395-27401, 1996. 

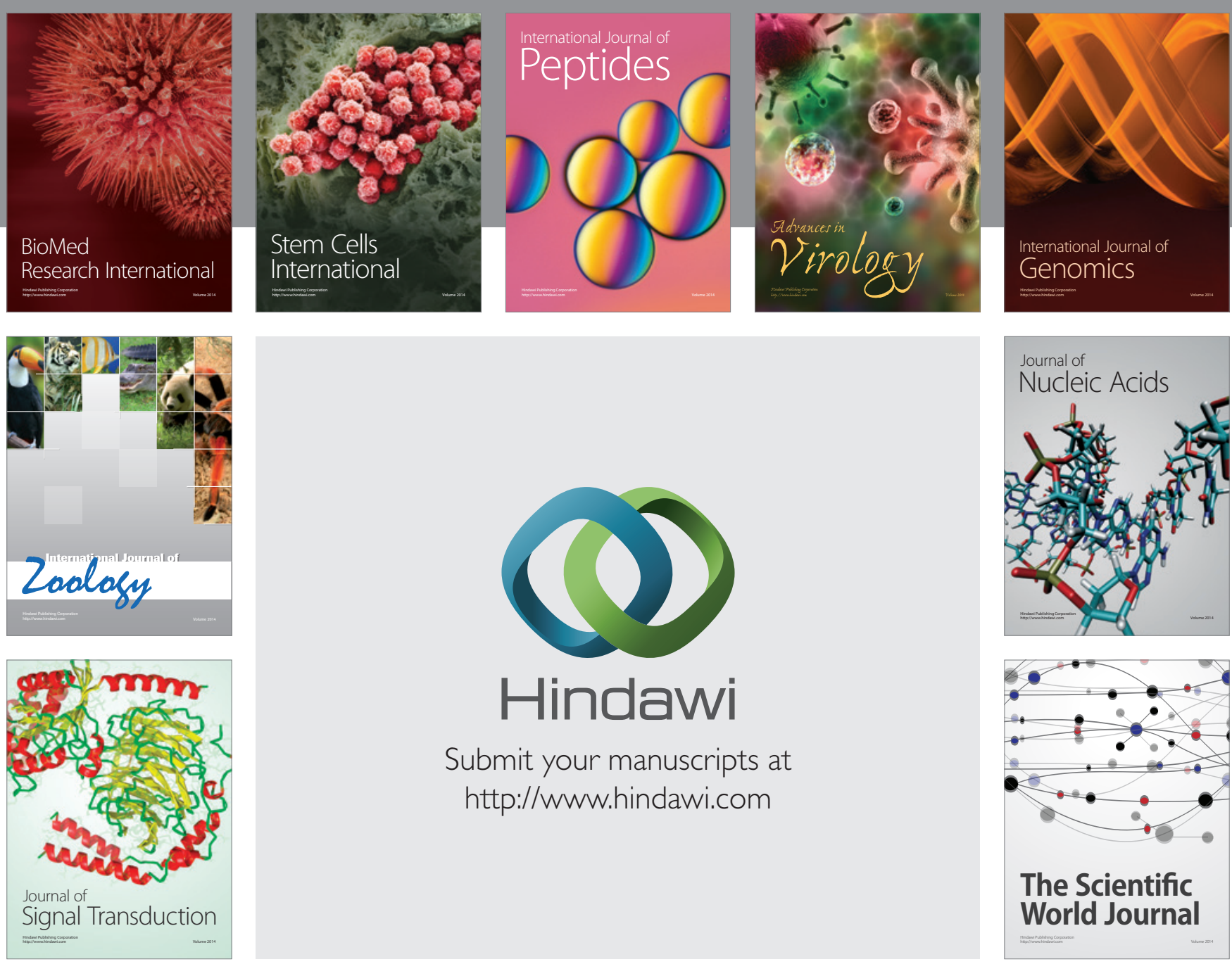

Submit your manuscripts at

http://www.hindawi.com
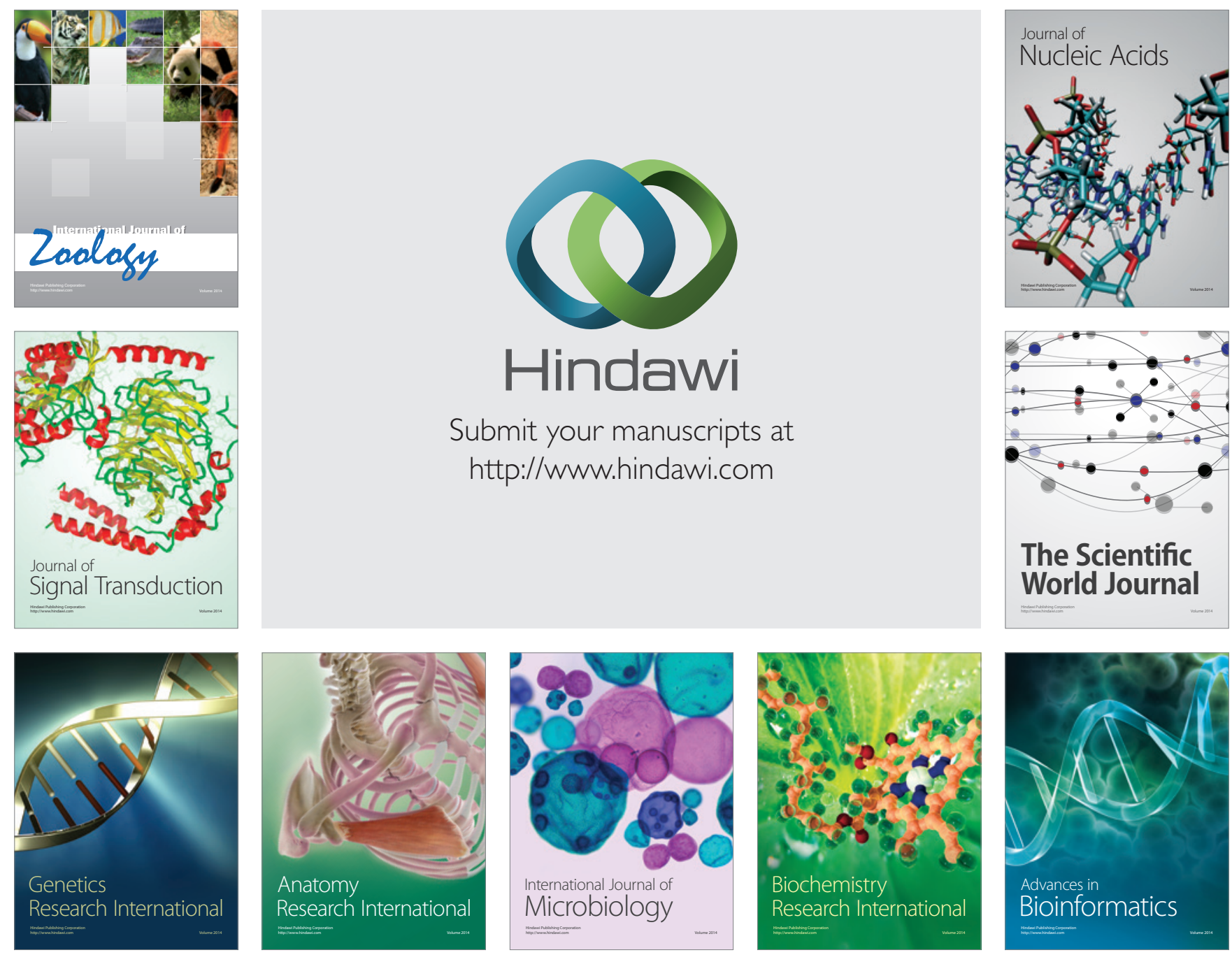

The Scientific World Journal
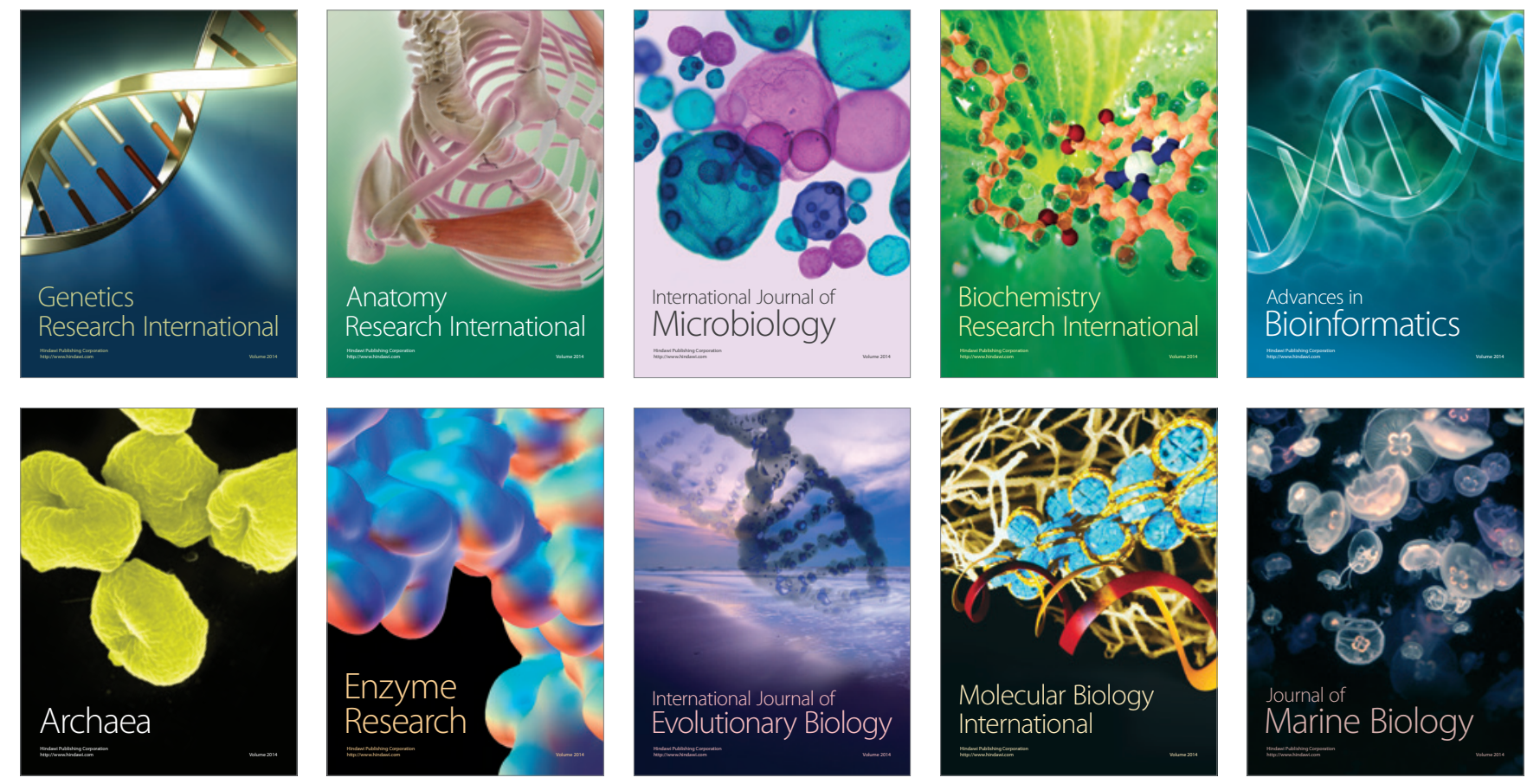